\title{
Growth of infants assisted in nursing appointments in childcare
}

\author{
Crescimento de lactentes atendidos na \\ consulta de enfermagem em puericultura \\ El crecimiento de los lactantes atendidos \\ en consulta de enfermería en el cuidado de los niños \\ Grazielle Cavalcante de Souza Carneiro ${ }^{a}$ \\ Lívia Maria Correia de Morais ${ }^{b}$ \\ Leidiane Francis de Araújo Costac \\ Talita Helena Monteiro de Mourad \\ Marly Javorski \\ Luciana Pedrosa Leal ${ }^{\mathrm{f}}$
}

D0l: $\quad$ http://dx.doi.org/10.1590/19831447.2015.01.45703

\begin{abstract}
This study aimed to describe the growth during the introduction of complementary feeding to infants assisted in the nursing appointment in childcare. It is a descriptive, cross-sectional, quantitative study developed through research in 51 medical records of children aged 4-8 months, from September to October 2012 in a university hospital in the city of Recife, PE. Data were analyzed using Epi Info software, version 6.04 and described in simple and relative frequencies. It was found that for $33 \%$ of the children. complementary foods were introduced at six months. Of these, $88.2 \%, 69.2 \%$ and $57.1 \%$ showed ascending weight-for-age growth curves, and $88.2 \%, 66.7 \%$ and $71.4 \%$ ascending length-for-age growth curves at six, seven and eight months respectively. Children with appropriate and timely introduction of complementary feeding showed upward growth curves and adequate nutritional status.
\end{abstract}

Keywords: Supplementary feeding. Nutritional status. Infant.Growth. Pediatric nursing.

\section{RESUMO}

Estudo que objetivou descrever o crescimento durante a introdução da alimentação complementar em lactentes atendidos na consulta de Enfermagem em puericultura. Estudo descritivo, transversal, quantitativo, desenvolvido por meio de pesquisa em 51 prontuários de crianças de quatro a oito meses, no período de setembro a outubro de 2012, em um hospital universitário localizado na cidade de Recife, PE. Os dados foram analisados no Epi Info versão 6.04 e descritos em frequência simples e relativa. Verificou-se que 33\% das crianças introduziram a alimentação complementar aos seis meses. Dessas, 88,2\%, 69,2\% e 57,1\% apresentaram as curvas de peso por idade ascendentes, e 88,2\%, 66,7\% e 71,4\% tiveram curvas de comprimento por idade ascendentes aos seis, sete e oito meses, respectivamente. Crianças com introdução correta da alimentação complementar apresentaram curvas de crescimento ascendentes e estado nutricional adequado.

Palavras-chave: Suplementação complementar. Estado nutricional. Lactente. Crescimento. Enfermagem pediátrica.

\section{RESUMEN}

Estudio tiene como objetivo describir el crecimiento durante la introducción de la alimentación complementaria en los niños tratados en la consulta de enfermería en el cuidado infantil. Estudio descriptivo, transversal, cuantitativo, desarrollado a través de la investigación de 51 casos de niños de cuatro a ocho meses, de septiembre a octubre de 2012, en un hospital universitario de la ciudad de Recife, PE. Los datos fueron analizados mediante Epi Info versión 6.04 y se describen en la frecuencia simple y relativa. Se encontró que 33\% de los niños presentó alimentos complementarios a los seis meses. De estos, $88,2 \%, 69,2 \%$ y $57,1 \%$ fue la edad ascendente versus curvas de peso y $88,2 \%, 66,7 \%$ y $71,4 \%$ de largo versus edad ascendente en seis, siete y ocho meses respectivamente. Los niños que introducen correctamente la alimentación complementaria mostraron curvas de crecimiento al alza y un estado nutricional adecuado. Palabras clave: Alimentación suplementaria. Estado nutricional. Lactante. Crecimiento. Enfermería pediátrica. 


\section{DINTRODUCTION}

The growth of human beings, a dynamic and continuous process, occurs in rapidly progressing stages, such as in the intrauterine period, in the first two years of life and puberty ${ }^{(1)}$. Evidence from epidemiological studies, animal models and clinical trials show the vulnerability of the early stages of life to nutritional and metabolic factors, which may determine changes in health and well-being of the individual ${ }^{(2)}$.

Growth monitoring by means of growth curves proposed by the World Health Organization (WHO) is important to monitor the nutritional status and behavior of the child's organism, allowing early interventions.

The Brazilian Ministry of Health recommends exclusive breastfeeding up to six months of age, complemented until two years, and gradual introduction of new foods at six months of age, allowing adaptation of the child to new tastes and textures ${ }^{(4)}$.

The introduction of complementary feeding is a complex stage for children and caregivers. In this period, the development of self-control of food intake by the child depends on the foods offered and how these are offered. This stage is influenced by knowledge on the normal behavior of children and the practice adopted by parents/caregivers and health professionals in the introduction of feeding, which may interfere with the nutritional status and behavior of growth curves ${ }^{(4)}$.

Children that begin complementary feeding before six months of age ${ }^{(3)}$ may suffer growth retardation, nutritional deficiencies, malnutrition or overweight ${ }^{(5-6)}$. Besides, infants under six months of age with breastfeeding associated to other foods or who are not breastfed are at increased risk of death by respiratory infection and diarrhea than infants exclusively breastfed ${ }^{(4,7)}$.

Despite its benefits to the child's health, in 2009 the prevalence of exclusive breastfeeding in infants under six months in Brazil was $41 \%{ }^{(8)}$. This situation can be associated to the influence of dairy advertisements, as well as individual, interpersonal and situational factors, social and cultural conditions that interfere with the choice of infant food. ${ }^{(9)}$.

As a strategy, the Ministry of Health elaborated the socalled "Ten steps to healthy eating", an important tool to guide health professionals in primary care ${ }^{(4)}$. In 2013, the strategies of promotion of breastfeeding and complementary feeding were unified in the network "Amamenta e Alimenta Brasil" (Breastfeed and Feed Brazil), which is aimed to improve the competencies of health professionals in their routine activities in Basic Health Units ${ }^{(10)}$.
In this context, the nursing appointment in childcare is an ideal situation for periodical and systematic monitoring of children and identification of health problems, in order to promote early intervention (11).

In these appointments, nurses should act as health educators, teaching mothers/caregivers on breastfeeding and the timely and appropriate introduction of complementary foods, contributing to the reduction of problems related to bad eating habits in childhood and adulthood ${ }^{(12-13)}$.

The identification of the association of bad eating habits and infant nutritional status can support the actions of nurses in childcare appointments. Thus, the question posed here is: what is the impact of the introduction of complementary feeding in the growth of infants represented in the weight-for-age growth curves?

The present study aims to describe growth during the introduction of complementary feeding in infants assisted in nursing childcare appointments.

\section{METHOD}

Descriptive, cross-sectional, quantitative study conducted in a hospital of the city of Recife, attached to Universidade Federal de Pernambuco (UFPE).

The population was composed of 146 infants assisted in nursing appointments in childcare in 2011. Monthly appointments with nurses are offered to healthy infants in the first year of life are offered in this service, which are not intercalated with medical appointments.

Intentional non-probabilistic sampling was used, and the sample consisted of 51 medical records of infants aged 4-8 months. This age range was selected considering the minimum age of four months for infants not exclusively breastfed to be introduced to complementary feeding, the 120-day maternity leave and the introduction of foods eaten by the rest of the family at eight months. Children introduced to complementary feeding after the sixth month of life were excluded. The data were collected from September to October 2012.

After the pilot study for testing the adequacy of the survey instrument and operation of data collection, the investigation of the daily feeding of the infants monthly described in the medical records was included. The 20 medical records that integrated the pilot study were revised for this item and included in the sample.

The form for data collection was composed of seven parts: identification of the infant, maternal data, socioeconomic conditions, housing and living conditions, history of 
eating habits (anamnesis), anthropometry and nutritional assessment. It contained closed questions and one open question concerning the reason for introduction of food before the sixth month of life.

Gender was used for characterizing the infants. Regarding the mothers, for biological and socioeconomic characterization, age, marital status, education, profession, family income (minimum wage of $R \$ 545,00$ ) and number of children under five years were analyzed. Housing and living conditions were assessed according to the type of housing, type of drinking water, availability of running water and basic sanitation in the household.

The variables related to the history of eating habits (anamnesis) concerned the information obtained by the mother or caregiver on the introduction of complementary feeding, the age of the infant when complementary feeding was introduced, the reason for introduction of food before the sixth month of life and maintenance of breastfeeding after introduction of complementary feeding. Also, the types of foods introduced according to the age range, the number of meals, the use of blender in food preparation and the occurrence of disease at the time of introduction of complementary feeding were characterized.

Concerning anthropometry and nutritional assessment weight and length were investigated and the behavior of growth curves (ascending, horizontal and descending) and nutritional classification (Z scores) were evaluated.

The data were processed and analyzed using Epi Info software, version 6.04. Data were assessed by descriptive analysis, with presentation of the categorical variables in simple and relative frequencies.

In the analysis, the introduction of appropriate complementary feeding was assessed based on the "Ten steps to healthy eating", recommended by the Ministry of Health. Children who received their first fruit puree and vegetable puree when aged six months and fifteen days, and that received the second vegetable meal when aged seven months were considered to be adequately nourished. ${ }^{(4)}$.

Given the lack of information in the medical records on anthropometric data at eight months, nutritional assessment was performed using the child's weight at the age of seven months, based on the nutritional classification recommended by the $W H O$, according to the following criteria: $>+2$ Z scores overweight); $\geq-2$ e $\leq+2$ Z scores (healthy weight) and $<-2$ Z scores (underweight) ${ }^{(14)}$.

Some cases were ignored due to lack of information in the medical records or because the child was not taken to the nursing appointment at the ages of six, seven or eight months.
The research was approved by the Research Ethics Committee of Centro de Cadencies da Saudi of UFPE, CAAE 03443712.0.0000.5208, No 249.943, according to Resolution 196/96 of the National Research Ethics Commission.

Article extracted from the monograph: "Growth of infants taken to nursing appointments in childcare in a teaching hospital in the city of Recife-PE"(15).

\section{RESULTS}

Regarding the infants, $51.6 \%$ were boys. As for the mothers, $87.7 \%$ were more than twenty years old, $88.4 \%$ were married, $69.1 \%$ had completed eight or more years of education and $42.1 \%$ did not work outside the home. Concerning the family income, $1.8 \%$ did not have any income and 40\% earned up to $R \$ 545.00$. Regarding the number of children under five years, for $65.5 \%$ of the mothers, they only had one child and $34.5 \%$ had two or more children.

Table 1. Age of introduction of complementary feeding, reason for early introduction and maintenance of breastfeeding in children taken to nursing appointments in a teaching hospital. Recife, 2012.

Variables

$n=51$ $\%$

\section{Age at introduction}

4 months $18 \quad 35.3$

5 months

$16 \quad 31.4$

6 months

17

33.3

Reason for introduction before the $6^{\text {th }}$ month of life *

$\begin{array}{lcc}\text { Use of infant formula } & 10 & 31.2 \\ \text { Return to work activities } & 6 & 18.8 \\ \text { Low weight gain } & 1 & 3.1 \\ \text { Maternal option } & 9 & 28.1 \\ \text { Use of whole milk } & 6 & 18.8\end{array}$

Maternal milk after introduction

\begin{tabular}{lll} 
Yes & 33 & 64.7 \\
No & 18 & 35.3 \\
\hline
\end{tabular}

Source: Research data, 2014

* 2 cases ignored 
Concerning housing and living conditions, 62.5\% lived in their own home, all houses were of typical masonry construction, $87.7 \%$ had water flowing through pipes, $84.2 \%$ had basic sanitation and $94.5 \%$ of the mothers had access to safe drinking water.

Regarding guidance on the introduction of complementary feeding, $64.9 \%$ of mothers or caregivers were instructed by the nurse during the appointment in childcare. Regarding the use of blender to prepare infant food, $65.5 \%$ of the mothers did not use this tool. At the time of intro- duction of complementary feeding, $72.9 \%$ of the children had diseases of respiratory, gastrointestinal, nutritional origin, among others.

Table 1 shows that of the $64.9 \%$ of mothers/caregivers who received guidance on feeding, 33.3\% introduced complementary foods to their babies at six months. Of those mothers who introduced complementary foods to their babies before six months of age, 31.2\% explained they were already using infant formulas and $28.1 \%$ decided to introduce foods earlier than recommended. Regard-

Table 2. Introduction of complementary feeding, according to recommendations of the Ministry of Health in children introduced to complementary foods at six months, taken to nursing appointments in childcare in a teaching hospital. Recife, 2012.

\begin{tabular}{|c|c|c|c|c|}
\hline \multirow{2}{*}{ Variables } & \multicolumn{2}{|c|}{ Yes } & \multicolumn{2}{|c|}{ No } \\
\hline & $\mathbf{n}$ & $\%$ & $\mathbf{n}$ & $\%$ \\
\hline Fruit puree at 6 months of age ${ }^{*}$ & 16 & 100 & - & - \\
\hline Fruit puree + vegetable puree at 6 months and 15 days ${ }^{* *}$ & 15 & 93.8 & 1 & 6.2 \\
\hline Second vegetable puree at 7 months of age & 10 & 76.9 & 3 & 23.1 \\
\hline Foods eaten by the rest of the family at 8 months of age ${ }^{* * * *}$ & 8 & 88.9 & 1 & 11.1 \\
\hline
\end{tabular}

Source: Research data, 2014.

${ }^{*} 1$ case ignored; ${ }^{* *} 1$ case ignored; ${ }^{* * *} 4$ cases ignored; ${ }^{* * *} 8$ cases ignored

Table 3. Behaviors of weight-for-age and length-for-age growth curves of children introduced to complementary feeding at six months of age taken to nursing appointments in childcare in a teaching hospital. Recife, 2012.

\begin{tabular}{|c|c|c|c|c|c|c|c|c|}
\hline \multicolumn{9}{|c|}{ Curve behavior } \\
\hline \multirow{2}{*}{ Variables } & \multicolumn{2}{|c|}{ Ascending } & \multicolumn{2}{|c|}{ Horizontal } & \multicolumn{2}{|c|}{ Descending } & \multicolumn{2}{|c|}{ Total } \\
\hline & $\mathbf{n}$ & $\%$ & $\mathbf{n}$ & $\%$ & n & $\%$ & n & $\%$ \\
\hline
\end{tabular}

\section{Weight-for-age growth curve}

$\begin{array}{lcccccccc}6 \text { months } & 15 & 88.2 & 2 & 11.8 & - & - & 17 & 100 \\ 7 \text { months* }^{*} & 9 & 69.2 & 3 & 23.1 & 1 & 7.7 & 13 & 100 \\ 8 \text { months* }^{*} & 4 & 57.1 & 3 & 42.9 & - & - & 7 & 100\end{array}$

\section{Length-for-age growth curve}

\begin{tabular}{lllllllll}
6 months & 15 & 88.2 & 2 & 11.8 & - & - & 17 & 100 \\
7 months** $^{* * 2}$ & 8 & 66.7 & 4 & 33.3 & - & - & 12 & 100 \\
8 months $^{* * * *}$ & 5 & 71.4 & 2 & 28.6 & - & - & 7 & 100 \\
\hline
\end{tabular}


Table 4. Behavior of growth curves and nutritional status regarding the indicator weight-for-age of children aged seven months, exclusively breastfed until the sixth month, according to the socioeconomic conditions, child's health and introduction of complementary feeding in a teaching hospital. Recife, 2012.

\begin{tabular}{|c|c|c|c|c|c|c|c|}
\hline \multirow{3}{*}{ Variables } & \multicolumn{3}{|c|}{ Weight x Age Curve } & \multicolumn{4}{|c|}{$\begin{array}{c}\text { Nutritional Status } \\
\text { Z scores (weight x age) }\end{array}$} \\
\hline & Ascending & $\begin{array}{r}\text { Ho } \\
\text { De }\end{array}$ & $\begin{array}{l}\text { l or } \\
\text { ing }\end{array}$ & $>+$ & res & $\geq-2$ & $+2 z$ \\
\hline & $\%$ & n & $\%$ & n & $\%$ & $\mathbf{n}$ & $\%$ \\
\hline
\end{tabular}

\section{Breastfeeding after the} $6^{\text {th }}$ month of life*

$\begin{array}{lllllllll}\text { Yes } & 9 & 69.2 & 4 & 30.8 & 1 & 7.7 & 12 & 92.3 \\ \text { No } & - & - & - & - & - & - & - & -\end{array}$

\section{Maternal schooling (years)**}

$\begin{array}{lllllllll}\leq 8 & 4 & 100 & - & - & - & - & 4 & 100 \\ >8 & 4 & 50 & 4 & 50 & 1 & 12.5 & 7 & 87.5\end{array}$

\section{Family income $(M W)^{* *}$}

$\begin{array}{lllllllll}\leq 2 & 7 & 70 & 3 & 30 & - & - & 10 & 100 \\ >2 & 1 & 50 & 1 & 50 & 1 & 50 & 1 & 50\end{array}$

No of children $<5$ years**

1

$$
66.7
$$

4

33.3

1

8.3

11

91.7

\section{Child was ill*}

Yes

No

\section{Introduction of feeding**}

\begin{tabular}{lcccccccc} 
Adequate & 7 & 87.5 & 1 & 12.5 & - & - & 8 & 100 \\
Inadequate & 2 & 50 & 2 & 50 & 1 & 25 & 3 & 75 \\
\hline
\end{tabular}

Source: Research data, 2014.

* 4 cases ignored; ** 5 cases ignored.

ing maintenance of breastfeeding after six months, $64.7 \%$ maintained breastfeeding.

Regarding the recommendations of the Ministry of Health for the introduction of complementary feeding, of the infants who were introduced to complementary feeding at six months of age: $100 \%$ received their first fruit puree at six months, $93.8 \%$ of them had already received a vegetable meal at six months and fifteen days, totaling three meals (Table 2). At seven months of age, $76.9 \%$ of the infants were receiving the second vegetable meal, and at eight months, $88.9 \%$ were eating the same as the rest of the family (Table 2).

Regarding the behavior of weight-for-age growth curves, $88.2 \% ; 69.2 \% ; 57.1 \%$ of the children aged six, seven and eight months, respectively, showed ascending curves. At seven months, 7.7\% had descending curves. At eight months, the curves for $42.9 \%$ of the children were flatter (Table 3). 
Regarding the behavior of length-for-age growth curves, $88.2 \% ; 66.7 \% ; 71.4 \%$ of the curves were ascending for children aged six, seven and eight months, respectively. At seven months, the curves for $33.3 \%$ were flatter (Table 3).

Concerning the behavior of growth curves, nutritional status and maintenance of breastfeeding after the sixth month, $69.2 \%$ of the children who continued to be breastfed showed ascending curves and $92.3 \%$ had an adequate nutritional status (Table 4).

The infants whose mothers had eight or less years of schooling showed $100 \%$ of ascending curves and adequate nutritional status, and the infants whose mothers had more than eight years of schooling showed $50 \%$ of ascending curves, $50 \%$ of descending or flatter curves and $87.5 \%$ had adequate weight. In households with a family income lower than two minimum wages, $70 \%$ of the children showed ascending curves and 100\% obtained adequate nutritional classification; in turn, of the infants from families with income higher than two minimum wages, 50\% had ascending curves and 50\% horizontal or descending curves (Table 4).

In families who had only one child, $91.7 \%$ of the children had appropriate weight. Regarding the children who were ill at the time of introduction of feeding, $75 \%$ had ascending curves and $91.7 \%$ had adequate nutritional status (Table 4).

Of the children who had timely and adequate introduction of complementary feeding, $87.5 \%$ had ascending curves and 100\% had adequate weight, and of those who had inadequate/untimely introduction of complementary feeding, 50\% had ascending curves, 50\% horizontal or descending curves and $75 \%$ had adequate nutritional status (Table 4).

\section{DISCUSSION}

In this study, the children who had adequate introduction of complementary feeding showed ascending growth curves and adequate nutritional status, an expected outcome for infants fed according to the recommendations of the Brazilian Ministry of Health. There are several factors associated to appropriate infant growth, and availability of food and the food preparation mode and use seem to be the main determinants ${ }^{(3)}$.

Regarding health assistance, most mothers were advised by the nurses to introduce complementary feeding at six months, which is the appropriate time to introduce new foods to meet the child's needs, while maintaining breastfeeding ${ }^{(16)}$. However, a significant number of infants received complementary feeding before six months of age, and the mothers provided the following explanations for this fact: they were not exclusively breastfeeding their infants; use of infant formulas or artificial milk; they had to return to their work activities or made the decision of introducing complementary feeding earlier than recommended. Although the children were monitored in childcare appointments, for 30\% of them the medical records did not include information on nursing guidance on the introduction of feeding.

Although frequently reported in the literature(13,17), these factors would not compel the mothers to introduce complementary feeding before the recommended time. The mothers who are required to stay away from their infants for some periods, should be encouraged to store breast milk for later use ${ }^{18}$, to ensure the maintenance of exclusive breastfeeding.

The use of infant formulas allows the introduction of complementary feeding at six months, without the need for supplemental iron and vitamins, and only in the case of infants not breastfed, and fed with cow's milk, complementary feeding should start at four months of age, with four daily meals, as follows: two basic meals (lunch and dinner), and two fruits, besides two milk meals without addition of sugar ${ }^{(4)}$.

Maintenance of breastfeeding, regardless of the age, did not occur for more than $30 \%$ of the infants after introduction of complementary feeding. The appropriate and timely introduction of food and breastfeeding up to two years are recommended for the child's growth and development ${ }^{(6)}$.

In the present study, all infants who were introduced to complementary feeding at six months of age were given fruit puree; for more than 93\%, the first vegetable meal was introduced at six months of age, and the number of mothers who introduced the second vegetable meal at seven months of age and the foods eaten by the family at eight months of age, as recommended by the Ministry of Health reduced gradually ${ }^{(2)}$. The fact that some mothers did not observe the feeding recommendations for their infants aged seven and eight months can be related to the percentage of children who had horizontal or descending weight-for-age growth curves and were overweight.

Despite the recommendations of the Ministry of Health, $34.5 \%$ of the mothers used blender to prepare the food, indicating that this practice persists. The health professionals should seek educational strategies aimed to change such behavior, by explaining to the mothers that blenderized foods do not stimulate chewing skills and have low energy density, and thus do not provide the amount of energy needed for the child to gain weight and be healthy ${ }^{(4)}$. 
Another factor to be considered is that adaptation of the child's body to new foods associated to inadequate preparation and conservation practices may predispose the infant to illnesses that will interfere in their healthy growth ${ }^{(16)}$. However, in this study, of the total number of children who became ill during the period of feeding transition, more than $75 \%$ maintained the weight-for-age growth curve and adequate healthy weight. It should be stressed that the Ministry of Health recommends providing an extra meal to the infant in the convalescence period so that the impact on growth is minimized ${ }^{(4)}$.

Regarding the behavior of growth curves in infants who were introduced to complementary feeding at six months of age, most curves at six, seven and eight months were ascending, which is considered a good health indicator. Regarding the children whose growth curves showed a horizontal or descending line, during the introduction of complementary feeding, the presence of signs and/or symptoms of pathological processes should be investigated. Also, special attention should be given to feeding, meal times, amount and energy content of foods, as well as to mother-infant relationship ${ }^{(16)}$. Just like the behavior of weight-for-age curves, regarding the nutritional status, the weight of most infants was appropriate for their age.

Similar data were reported in a study at the "Centro de incentivo e apoio ao aleitamento materno" of Universidade Federal de São Paulo (CIAAM/Unifesp) with infants aged between six months and one year, in the second half of 2007, where it was found that most children had an appropriate weight for their age, and a small percentage was underweight at three measurement times. Most children had appropriate height (length) for their age ${ }^{(19)}$.

\section{CONCLUSIONS}

The growth curves were ascending and the nutritional status was appropriate for the age of the infants who were timely and adequately introduced to complementary feeding. However, the number of medical records that did not include information on the introduction of complementary feedings, even when the children were taken to nursing appointments in childcare, indicates that some nurses do not give priority to dietary guidance in child and family care.

A significant percentage of children became ill during the period of introduction to complementary feeding, which stresses the need for greater concern about these infants.

It is expected that these findings are used in clinical practice by health professionals in the planning of actions aimed at preventing diseases and promoting healthy growth in childcare appointments. Intervention studies aimed at improving systematization of nursing care in child health are recommended.

In this study, the small sample size did not allow estimating the statistical association between some variables such as family income, maternal schooling and nutritional status of the child. Further studies with more representative samples may provide this investigation.

\section{Q REFERENCES}

1. Silva CAA, Pereira MJB, Nakano AMS, Gomes FA, Silva IA. Concordância dos referenciais de crescimento propostos pelo Center of Disease Control e Organização Mundial de Saúde. Rev Esc Enferm USP. 2011;45(2):404-10.

2. Caetano MC, Ortiz TT, Silva SGL, Souza FIS, Sarni ROS. Complementary feeding: inappropriate practices in infants. J Pediatr. 2010;86(3):196-201.

3. Ministério da Saúde (BR), Secretaria de Políticas de Saúde, Departamento de Atenção Básica. Saúde da criança: crescimento e desenvolvimento.Brasília; 2012.

4. Ministério da Saúde (BR). Dez passos para uma alimentação saudável: guia alimentar para menores de dois anos: um guia para o profissional de saúde na atenção básica. 2. ed.Braśilia;2013. v. 2.

5. Corrêa EN, Corso ACT, Kazapi I, Moreira EAM. Alimentação complementar e características maternas de crianças menores de dois anos de idade em Florianópolis/SC. Rev Paul Pediatr. 2009;27(3):258-64.

6. Correia PP, Pereira SMPD, Brito LAMH. Alimentação de transição infantil: conhecer para educar. Rev Cienc Saúde. 2013;6(2):85-93.

7. Araújo, MFM, Ferreira AB, Gondim KM, Chaves ES. A prevalência de diarréia em crianças com uma amamentação ausente ou inferior a seis meses. Rev Rene. 2007:8(3):69-76.

8. Ministério da Saúde (BR), Secretaria de Atenção à Saúde, Departamento de Ações Programáticas e Estratégicas. Prevalência do aleitamento materno nas capitais brasileiras e no Distrito Federal. Brasília; 2009.

9. Monteiro RA, Pereira BPA. Publicidade que alimenta: análise das estratégias destinadas à criança na publicidade de alimentos na mídia impressa brasileira. Comunicologia. 2012;15(1):110-31.

10. Ministério da Saúde(BR), Gabinete do Ministro. Portaria no 1.920 de5 de setembro de 2013.Institui a Estratégia Nacional para Promoçãodo Aleitamento Materno e AlimentaçãoComplementar Saudável no Sistema Únicode Saúde (SUS) - Estratégia Amamenta e Alimenta Brasil.Diário Oficial da União [da] República Federativa do Brasil. 2013 set06;150(173 Seção 1):64-5.

11. Campos RMC, Ribeiro CA, Silva CV, Saparolli ECL. Consulta de enfermagem em puericultura: a vivência do enfermeiro na Estratégia de Saúde da Família. Rev Esc Enferm USP.2011;:45(3):566-74.

12. Alves TD, Pereira GA, Bonfim SFSF, Javorski M, Vasconcelos MGL, Leal LP. Prática dos enfermeiros no manejo da alimentação de crianças menores de 1 ano de idade. Rev Enferm UFPE. 2011 dez; 5(nesp):2651-9.

13. Gomes AC, Lima JCA, Javorski M. Os dez passos para alimentação saudável em crianças menores de dois anos acompanhadas pela Estratégia de Saúde da Família: prática ou utopia? Rev Enferm UFPE. 2011 jun;5(4):957-66.

14. World Health Organization (SW). WHO child growth standards: length/height-for-age, weight-for-age, weight-for-length, weight-for-height and body mass index-for-age. Methods and development. Geneva; 2006. 
15. Souza GC, Morais LMC. Crescimento de lactentes atendidos na consulta de enfermagem em puericultura em um hospital escola da cidade do Recife-PE [monografia]. Recife: Universidade Federal de Pernambuco; 2013.

16. Javorski M. Puericultura: condutas para o acompanhamento do crescimento e desenvolvimento de crianças de zero a dois anos nas consultas de enfermagem. Recife: Editora Universitária; 2010.

17. Silva LMP, Venâncio SI, Marchioni DML. Práticas de alimentação complementar no primeiro ano de vida e fatores associados. Rev Nutr. 2010; 23(6):983-92.
18. Agência Nacional de Vigilância Sanitária (BR). Portaria nº 193, de 23 de fevereiro de 2010. Dispõe sobre a instalação de salas de apoio à amamentação em empresas públicas e privadas. Diário Oficial da União [da] República Federativa do Brasil. 2010fev 24;147(36 Seção 1):98-9.

19. Pires BS, Akutsu RC, Coelho LC, Asakura L, Sachs A, Abrão ACVF, et al. Comparação entre as curvas de crescimento do Centers for Disease Control and Prevention e da Organização Mundial da Saúde para lactentes com idade de seis a 12 meses. Rev Paul Pediatr. 2010;28(4):314-9.

\section{Author's address:}

Marly Javorski

Rua Jacauna, 225/102, Iputinga

50721-480, Recife, PE

E-mail: marly.11j@gmail.com
Received: 16.03.2014

Approved: 05.12.2014 